\title{
The Influence of Work Ethic on Public Services: Lessons from a Distant Indonesian Local Public Organization
}

\section{Leonardus Mangago}

Faculty of Social and Political Sciences, Universitas Terbuka, Indonesia

Email: leonardusangalla@gmail.com, 500661151@ecampus.ut.ac.id

\begin{abstract}
:
This research aimed to identify and analyze the principles, standards, elements, and quality of public services at the Office of Industry, Trade, and Cooperatives of Yahukimo Regency, Indonesia, located in a remote area. The research method applied was a qualitative descriptive survey with observation and interviews. The interviewees in this study were from 15 informants of different position levels. This study employed an interactive model to analyze the interview data. There were four main findings; firstly, in terms of the principle of public service transparency, the public was increasingly motivated to convey their demands, requests, and aspirations to the government. Meanwhile, accountability services were satisfactory per the provisions of laws and regulations, but public participation in public services was still lacking. Secondly, public service standards and service procedures were implemented following the stipulated provisions and competencies of officials. Those public officers had related-abilities in the form of knowledge, prowess, skill, attitude, and behavior that are required in completing their duties. Thirdly, in terms of public services, the public officers' work ethic was a driving force for the officials to comply with the prior-set and agreed with rules and work procedures. At the same time, the facilities and infrastructure were adequate. Finally, regarding the quality of public services, the goals and targets of the service were well achieved.
\end{abstract}

Keywords:

work ethic; public service; distant local government

\section{Introduction}

Managing and optimizing the public officers are the main challenge for every local government, either in the urban areas or remote ones (Heath \& Palenchar, 2008). It becomes a severe problem for local governments in distant regions where accessibility is limited (Muñuzuri et al., 2005). Similar challenges are becoming the Indonesian government's main priorities to tackle these shortcomings (Hanis, 2012). Therefore, it is not surprising that local government's human resource management is a vital issue and in the highlight of the eight programs in the bureaucratic reform roadmap for the period 2010-2014 (Rante \& Warokka, 2016). One of the mandatory activities in the bureaucratic reform program is government agencies' obligation to conduct and develop individual appraisals on employee performance (Wihantoro et al., 2015).

Individual appraisal on employee performance is a challenging task compared to other tasks in human resource management, such as placement, development, and promotion or dismissal of employees (Grubb, 2007). Some of the problems in appraisal on employee performance include determining appropriate performance indicators for each employee according to their position, performance targets for each employee concerning organizational planning, and the media to record employee performance achievements ( Na-Nan et al., 2020). Therefore, some human resource management experts argue that employee performance appraisal is the most critical stage in employee management (O'Boyle, 2013). 
The performance appraisal on civil servants (PNS) has been carried out based on the List of Appraisal of Employee Work Implementation (DP3). This system is according to Government Regulation Number 10 of 1979, in which employee performance is assessed on the eight elements that are inherent in the personality of the employee concerned. However, the assessment model is considered to have many weaknesses. These weaknesses include: [1] the DP3's inability to measure the employee's productivity and contribution, [2] less informative in informing the employee's failures and successes doing their duties, and [3] it is not based on target objectives. Therefore, the assessment process tends to be biassed and subjective (Rahmat, 2011).

One method of developing human resources quality is by providing training. With the rapid development of knowledge and technology, employee training programs are critical to advance the organization (Tasca et al., 2010). Law Number 5 of 2014 concerning State Civil Administration states that in order to achieve maximum effectiveness and efficiency, there will be arrangements and implementation of education and training for civil servants to increase service, quality, expertise, ability, and skills. It explains the vital role of civil servants or public officers as human resources in supporting government organizations' advancement.

The same challenge happens in the Yahukimo Regency, located in a distant eastern part of Indonesia (i.e., Papua region), to implement the public officers' developmental program. It is facing the problem of inadequate and unqualified human resources to serve the public effectively. This challenge makes the local government challenging to realize its vision and mission statements (Luthans \& Youssef, 2004). The government has a vital role in providing excellent public services for all citizens (Rukayat, 2018). Law Number 25 of 2009 concerning Public Services explains that public service is an activity or series of activities to fulfill the service's needs under regulations for each citizen and resident of goods, services, and administrative services provided by the public service organizer. In other words, public service, which is an effort made by a group or a bureaucracy to assist the public in achieving a particular goal, is a proxy or representative of government presence to its people (Moenir, 2006).

The public officers govern public affairs based on the society's initiative and aspirations. However, in reality, the implementation of public services by the government is still tinged with ineffective and inefficient services and inadequate quality of human resources. It can be seen from the many complaints from the public, demanding the quality of public services to be improved (Mahendra et al., 2014). Improving the quality of public services is a crucial issue (Hartley, 2005) because, on the one hand, public demands for service quality are getting bigger, while on the other hand, the practices implemented by service providers have not changed significantly (Nuriyanto, 2014). Public demands good-quality public services at all times, although these demands are often not in line with expectations because public services have been red tape, slow, costly, and tiresome (Mahsyar, 2011).

To tackle this lacking of excellent public service, the Yahukimo Regency could assign and allocate a particular budget and program in education and training. This education and training program would improve the knowledge, skills, and abilities of public officers (Jehanzeb \& Bashir, 2013). So, civil servants within the office can do their duties and activities properly to achieve predetermined goals. However, the preliminary observation showed that the performance of Yahukimo Regency's public officers is not optimal. The causes were: [a] a lack of work ethic, $[\mathrm{b}]$ an inadequate level of education, and [3] the mismatch between the public officers' educational background and their assigned jobs. Those weaknesses lead to the 
poor quality of work and service received by local society as the main clients or customers. Therefore, this research aimed to identify and analyze the quality of public service's principles, standards, and work-elements, compared to Law Number 23 of 2014, by conducting in-depth interviews with the relevant informants.

\section{Review of Literatures}

\subsection{Public Service}

Grout and Stevens (2003) defined public service as any service provided for large numbers of citizens. There is a potentially significant market failure (broadly interpreted to include equity and efficiency) justifying government involvement in production, finance, or regulation (Warokka, 2013) when the public organization provides the services. Further, Spicker (2009) explained that public services have four defining characteristics: [1] exist for policy reasons; [2] provide services to the public; [3] are redistributive, and [4] act as a trust.

\subsection{Principles of Public Service}

Public services must always follow the change in society because society is dynamic (Hartley, 2005). In this case, the government must negotiate and collaborate on various public interests so that public services have the quality that is in line with public expectations.

Sinambela et al. (2011) suggested the principles in public service are as follow:

1) Transparency. Public service is transparent, simple, accessible to all parties in need, provided adequately, and understandable.

2) Accountability. Public service can be accounted for following the provisions of laws and regulations.

3) Being conditional. Public service is under the conditions and capabilities of service providers and recipients by adhering to efficiency and effectiveness.

4) Participatory. Public service encourages public participation in its implementation by considering public aspirations, needs, and expectations.

5) Equal rights. Public service must be non-discriminatory in the sense of not discriminating against a particular ethnicity, religion, race, social class, gender, and economic status.

6) Being balance between rights and responsibilities. Providers and recipients of public services must fulfill the rights and responsibilities of each party.

\subsection{Quality of Public Services}

According to Sasser et al. (1978), two main factors influence service quality: respected service and perceived service. If the perceived service matches expectations, the service quality is perceived as ideal. Conversely, if the perceived service is lower than expectations, then the perceived service quality is terrible. Whether or not the quality of service depends on service providers' ability to meet customer expectations consistently. So, quality service is not only determined by the party who provides service but also the party being served. 


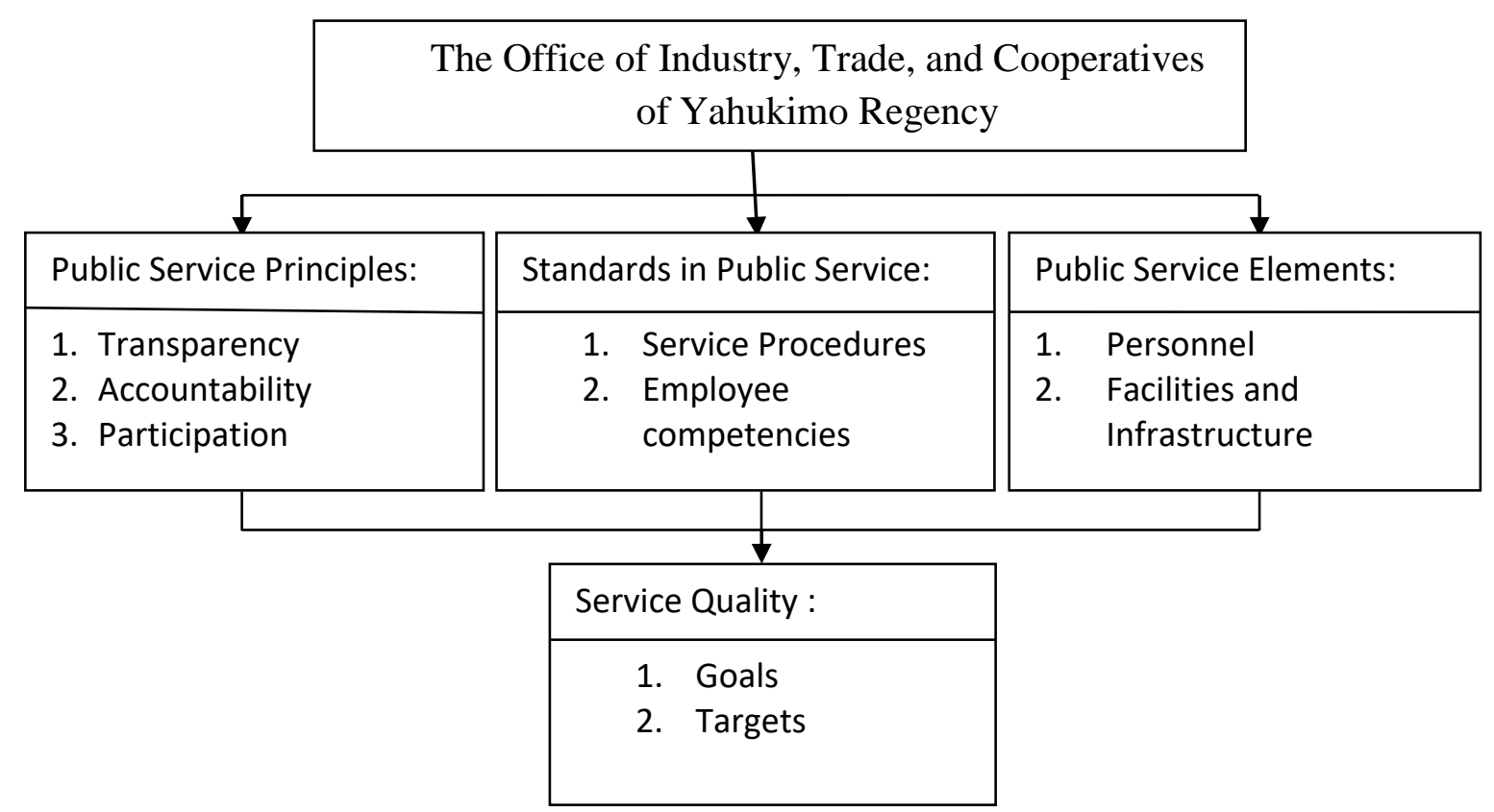

Figure 1. Research Framework

\section{Research Methods}

This research used a qualitative descriptive survey in which the research was purposed to describe the state of public services. The design of this research provided a factual description of public service principles, public service standards, public service elements, and quality of public services at the Yahukimo Regency. Primary data were obtained directly from interviewees via observation and interview, while secondary data were obtained from documents and reports related to research problems. The interviewees in this research were from 15 different position levels in the Office of Industry, Trade, and Cooperatives of Yahukimo Regency. The data analysis technique used was the qualitative method with an interactive model. In the interactive model, there are three components to be analyzed, namely, reduction, data presentation, and conclusion (Miles \& Huberman, 1992). Furthermore, the analysis was conducted by interactively integrating the three components. To ensure the validity of the findings, data triangulation, which comprised methodological triangulation, data triangulation, and time triangulation, was conducted

\section{Results and Discussion}

\subsection{Public Service Principles \\ a. Transparency}

The main principle in budget transparency is that information related to budget planning is every citizen's right (Dawes, 2010). The information referred to is information related to budget planning documents and activities. Meanwhile, transparency in public services is the implementation of tasks and activities open to the general public. The policy process, planning, implementation, and monitoring must be open and easily accessible to all parties who need information.

"Transparansi itu berarti bersifat terbuka, mudah, dan dapat diakses oleh semua pihak yang membutuhkan dan disediakan secara memadai serta mudah dimengerti."

"Transparency means that it is open, easy, and accessible to all parties who need it and is provided adequately and is easy to understand." (MP, Head of Cooperatives Division) 
"Transparansi mensyaratkan bahwa pelaksana pelayanan publik memiliki pengetahuan tentang permasalahan dan informasi yang relevan dengan yang kegiatan pelayanan."

"Transparency requires that public service implementers know issues and information that are relevant to service activities." (LB, Cooperatives and SME Section).

"Konteks transparansi pelaksana pelayanan publik, pelaksana harus terbuka pada setiap tindakannya dan siap menerima kritikan maupun masukan, terutama yang dapat dari masyarakat adalah merupakan kebutuhan utama agar aparatur memahami aspirasi riil masyarakat."

"(In) the context of transparency in implementing public services, the implementer must be open to every action and ready to accept public critique and suggestions, which are the main need for them to understand the real public aspirations." (VW, Training and Counseling Section)

"Keterbukaan sangat diperlukan untuk mengurangi peluang timbulnya perilaku aparatur yang dapat merugikan negara dan masyarakat."

"Openness is necessary to reduce the chances of civil servant behavior that can harm the state and public." (JP, Company Information and Registration Section)

Transparency is an effort to create mutual trust between the government and the public by providing information and ensuring the convenience of obtaining accurate and adequate information. Indicators to measure this transparency include the management and implementation of public services, service procedures, technical and administrative requirements of services, details of service charges, service completion times, authorized and responsible officials, service locations, service promises, public service standards, and information service.

“Transparansi yaitu adanya kebijakan terbuka bagi pengawasan. Sedangkan yang dimaksud dengan informasi adalah informasi mengenai setiap aspek kebijakan pemerintah yang dapat dijangkau oleh publik."

Transparency is the availability of policy that allows for monitoring. Meanwhile, what is meant by the information here is information about every aspect of government policy that is accessible to the public." (JP, Head of Section of Company Registration)

The results of the interview above indicated that information disclosure was expected to result in fair and tolerant political competition and policies that were made based on public preferences. This principle has two aspects: [1] public communication by the government and [2] public right to access information. Both will be very difficult to do and be fulfilled if the government does not perform correctly.

"Transparansi berarti keterbukaan pemerintah dalam memberikan informasi yang terkait dengan aktivitas pengelolaan sumber daya publik kepada pihak-pihak yang membutuhkan informasi."

"Transparency means the openness of the government in providing information related to public resource management activities to those who need information." (MH, Head of the Office of Trade, Industry, and Cooperative of Yahukimo Regency) 
"Pemerintah berkewajiban memberikan informasi keuangan dan informasi lainya yang akan digunakan untuk pengambilan keputusan oleh pihak-pihak yang berkepentingan."

"The government is obliged to provide financial information and other information that interested parties will use for decision making." (MD, Handicraft Coaching and Development Section)

"Pada akhirnya transparansi akan menciptakan horizontal accountability antara pemerintah daerah dengan masyarakat sehingga tercipta pemerintahan daerah yang bersih, efektif, efisien, akuntabel, dan responsif terhadap aspirasi dan kepentingan masyarakat."

"In the end, transparency will create horizontal accountability between the local government and public to create fair, effective, efficient, and accountable local government that is responsive to public aspirations and interests." (AR, Food, and Beverage Industry Development Section)

"Transparansi adalah sebuah prinsip yang menjamin akses atau kebebasan bagi setiap orang untuk memperoleh informasi tentang penyelenggaraan pemerintahan, yakni informasi tentang kebijakan, proses pembuatan dan pelaksanaannya serta hasil-hasil yang dicapai."

"Transparency is a principle that guarantees access or freedom for everyone to obtain information about governance, which is information about policies, the process of policy-making and implementation, and the results achieved." (FS, Section of Business Development and Consumer Protection)

The meaning of transparency in regional governance can be seen in two ways, namely: 1) Manifestation of government accountability to the people, and 2) Efforts to improve governance management and good governance and to reduce opportunities for collusion, corruption, and nepotism practices (Agere, 2000). In the transparency of regional government administration, it is necessary to pay attention to the following points: 1) Publication and dissemination of local government policies, 2) Publication and dissemination of regulations issued by local governments regarding various permits and procedures, 3) Publication and dissemination of procedures and work procedures of local government; 4) Transparency in bidding and awarding tenders or contracts for local government projects to third parties, and 5) Opportunities for the public to access fair, accurate, and non-discriminatory information (Debrah, 2011).

From the results of the interviews, most interviewees said that transparency had been well. Therefore, it can be concluded that the transparency in the Office of Industry, Trade, and Cooperatives of Yahukimo Regency was good. This fact is because the dissemination of various information, which only the government has access to, can provide opportunities for various components of society to participate in decision making.. Also, transparency can help reduce opportunities for corruption among public officials because all decision-making processes and their implementation are "visible" to public

\section{b. Accountability}

Accountability is a term that was initially applied to measure whether public funds have been used appropriately for the purpose for which they have been determined and have not been used illegally. In its development, the government also uses accountability to assess economic efficiency to find whether there are violations by staff, inefficiencies, and unnecessary procedures (Wang, 2002). 


\begin{abstract}
"Membedakan akuntabilitas dan responsibilitas, menurutnya keduanya merupakan hal yang saling berhubungan tetapi akuntabilitas lebih baik dan berbeda dengan responsibilitas. Akuntabilitas didasarkan pada catatan/laporan tertulis sedangkan responsibilitas didasarkan atas kebijaksanaan."

Accountability and responsibility, in my opinion, are both interrelated, but accountability is better and different from responsibility. Accountability is based on written records or reports, while responsibility is based on discretion." (MH, Head of the Office of Trade, Industry, and Cooperatives of Yahukimo Regency)
\end{abstract}

Based on the interview above, accountability refers to the "check and balance" mechanism of an institution's administrative system. Accountability is a common characteristic of asymmetric authorization relationships, for example, between the supervised and the supervisor, the agent and the principal, or the representative and the represented.

\begin{abstract}
"Membedakan akuntabilitas dalam arti sempit dan arti luas, akuntabilitas dalam pengertian yang sempit dapat dipahami sebagai bentuk pertanggungjawaban yang mengacu pada siapa organisasi (atau pekerja individu) bertangung jawab dan untuk apa organisasi bertanggung jawab. Sedangkan pengertian akuntabilitas dalam arti luas dapat dipahami sebagai kewajiban pihak pemegang amanah (agen) untuk memberikan pertanggungjawaban, menyajikan, melaporkan, dan mengungkapkan segala aktivitas dan kegiatan yang menjadi tanggung jawabnya kepada pihak pemberi amanah (principal) yang memiliki hak dan kewenangan untuk meminta pertanggungjawaban tersebut." (DS, Sekretaris Diknas Perdagangan, Perindustrian dan Koperasi Kabupaten Yahukimo).
\end{abstract}

Accountability can be understood in a narrow and broad sense. Accountability in a narrow sense is a form of responsibility that refers to who the organization (or individual worker) is responsible for and what the organization is responsible for. Meanwhile, accountability in a broad sense can be understood as the obligation of the agent to provide accountability and present, report, and disclose all activities that become their responsibility to the principal who has the right and authority to hold them accountable." (DS, Secretary of the Office of Trade, Industry, and Cooperatives of Yahukimo Regency)

Accountability is the obligation to answer and explain the performance of an individual, legal entity, or leader of an organization to parties who have the right or authority to request information or accountability (Székely \& Knirsch, 2005).

"Akuntabilitas sebagai pertanggungjawaban pihak yang diberi kuasa mandat untuk memerintah kepada yang memberi mereka mandat. Akuntabilitas bermakna pertanggungjawaban dengan menciptakan pengawasan melalui distribusi kekuasaan pada berbagai lembaga pemerintah sehingga mengurangi penumpukkan kekuasaan sekaligus menciptakan kondisi saling mengawasi."

Accountability is the responsibility of those given the mandate to govern those who give them the mandate. Accountability means creating supervision through the distribution of power in various government agencies to reduce the accumulation of power and at the same time, to create conditions for mutual control." (CT, Head of General Affairs Subdivision) 
"Akuntabilitas LAK yang memadai dapat berbentuk laporan yang dapat mengekspresikan pencapaian tujuan melalui pengelolaan sumber daya suatu organisasi, karena pencapaian tujuan merupakan salah satu ukuran kinerja individu maupun unit organisasi."

"Adequate performance accountability report can be in the form of a report that can express the achievement of goals through the management of organizational resources because the achievement of goals is a measure of the performance of individuals and organizational units." (FA, Head of Finance Subdivision).

It showed that the government also required employees to prepare a Performance Accountability Report (LAK). With the Performance Accountability Report, all government agencies can convey their accountability in a concrete form to achieve organizational vision and mission statement.

"Dinas Perdagangan Perindustrian dan Koperasi yang menggunakan Laporan Akuntabilitas Kinerja untuk mengukur akuntabilitas kinerja pegawai."

"The Office of Trade, Industry, and Cooperatives uses the Performance Accountability Report to measure the accountability of employee performance." (SR, Head of Program Subdivision)

"Dalam upaya mewujudkan akuntabilitas secara internal, telah dirancang dan diterapkan sejumlah statement of procedure yang akuntabel sehingga kinerja pegawai lebih memuaskan bagi para anggota. Statements of procedure yang telah disusun dan diterapkan antara lain adalah statement of procedure untuk pencarian dana (fundraising), pengelolaan keuangan, penetapan personil proyek, dan sebagainya. Penyelenggaraan pelayanan harus dapat dipertanggungjawabkan, baik kepada publik maupun kepada atasan/pimpinan unit pelayanan instansi pemerintah, sesuai dengan ketentuan peraturan perundang-undangan."

"In order to achieve internal accountability, some accountable statements of procedure have been designed and implemented so that personnel performance is more satisfying for members. Statements of procedure that have been prepared and implemented include statements of procedure for fundraising, financial management, assignment of project personnel, and other related things. The provision of services must be accountable, both to the public and to the superiors/leaders of the service units of government agencies following the provisions of laws and regulations. (MP, Head of Cooperatives Division)

"Pejabat/petugas, yang berwenang dan bertanggung jawab memberikan pelayanan dan/atau menyelesaikan keluhan, persoalan dan sengketa, diwajibkan memakai tanda pengenal di tempat kerja dan menaruh papan nama di meja. Pejabat atau petugas tersebut harus ditetapkan secara formal berdasarkan Surat Keputusan atau Surat Penugasan dari pejabat yang berwenang."

"Officials or officers, who are authorized and responsible for providing services and/or resolving complaints, problems, and disputes, are required to wear ID card and put desk nameplate. The official or officer must be formally appointed based on Ministerial Decision or Letter of Assignment from the authorized official." (DS, Secretary of the Office of Trade, Industry, and Cooperatives of Yahukimo Regency) 
The results of interviews indicated that the accountability at the Office of Industry, Trade, and Cooperatives of Yahukimo Regency had been well. The informants claimed that they had implemented the accountability principle by following the standard operating procedure set by the regulations. Accountability for the implementation of government services should be oriented towards public interests. With this paradigm, good quality public services can be realized. If, in practice, some civil servants behave in an unfriendly manner, service recipients can file complaints, and public services will not be disrupted.

\title{
c. Participation
}

There are many violations in public services implementation due to the imbalance of information control between the public and government. The rampant corruption of the regional government budget (APBD) occurs due to the intransparent access to information related to regional government budget documents. The paradigm that the government budget document is secret information and not everyone has access to this information has caused the public to lose control over government administration practices (Bovaird, 2007; Warokka, 2013). In contrast, public services monitoring is only possible when the public has adequate information about public documents.

Even though they already know the importance and benefits of participation in public services, in many cases, the government often deceives the public by making participation only jargon to gain public legitimacy. Therefore, it is necessary to identify methods or instruments that can be used to increase participation. Participation is a central concept and fundamental principle of community development. In many things, participation is closely related to the idea of human rights. In this sense, participation is an end in itself, which means that participation activates the idea of human rights to participate in democracy and to strengthen deliberative democracy. As a process in community development, participation is related to human rights in other ways (Eversole, 2012).

Protecting human rights is more than just a statement in a declaration. That is when public participation results in actively building a human rights culture, then ensuring that processes in participatory community development contribute to developing a human rights culture. Human rights culture is a culture in which the participation of citizens is expected and become a normal process in decision making (Irvin \& Stansbury, 2004). In this case, participation is both a tool and a goal because it forms part of the cultural foundation that paves the way to realizing human rights.

\begin{abstract}
“Dalam partisipasi harus mencakup kemampuan rakyat untuk memengaruhi kegiatan-kegiatan sedemikian rupa sehingga dapat meningkatkan kesejahteraannya. Arti partisipasi sering disangkutpautkan dengan banyak kepentingan dan agenda yang berbeda yang berlangsung dalam kehidupan masyarakat dan pembuatan keputusan secara politis."

Participation must include the people's ability to influence activities in such a way so as to improve their welfare. The meaning of participation is often associated with many different interests and agendas in public life and political decision making." (MU, Handicraft Coaching and Development Section)
\end{abstract}

"Partisipasi masyarakat merupakan hak dan kewajiban warga negara untuk memberikan kontribusinya kepada pencapaian tujuan kelompok. Sehingga mereka diberi kesempatan untuk ikut serta dalam pembangunan dengan menyumbangkan inisiatif dan kreativitasnya." 
"Public participation is the right and obligation of citizens to contribute to the achievement of collective goals. So, they are allowed to participate in the development by presenting their initiatives and creativity." (YB, Industrial Training and Development Section).

Based on the results of the interview above, it can be concluded that public participation is participation in the process of identifying public issues and potential. Meanwhile, public participation in public services was still low due to several factors, including, firstly, low education levels, which result in low levels of public participation. Secondly, people classified as "poor" tended not to have the resources to participate actively (Cattell, 2001). It was because they did not have enough information, did not have the opportunity to build networks as part of the social capital of society. Thirdly, there were sociocultural barriers that made people reluctant to be involved in the service system at the minor community groups (Barth, 2010). Some parties did not allow them to convey their aspirations actively, and the culture of silence was more dominated. Finally, there was a lack of public trust in the government, which created public apathy in the public service process.

\subsection{Quality of Public Services a. Goals}

The government, as a provider of public services, must continuously improve its service quality. One of the efforts to improve the quality of public services, as mandated in the Law of the Republic of Indonesia Number 25 of 2000 concerning the National Development Program (PROPENAS), is the development of public satisfaction index as a benchmark for assessing service quality. The Public Satisfaction Index (IKM) is data and information about the level of public satisfaction. It is based on quantitative and qualitative measurements of public opinion regarding their experience with services provided by public service administrators by comparing their expectations and their needs (Decree of the Minister for Administrative and Bureaucratic Reform Number 25 of 2004).

Also, data based on the Public Satisfaction Index will be used as an assessment material for service elements that need to be improved and motivated for each service provider unit to improve their service quality. The Public Satisfaction Index is intended to become a reference for service units of government agencies to determine the level of performance of service units regularly as material for policy-making in order to improve public service quality further (Yang \& Holzer, 2006). For the public, the Public Satisfaction Index can be used as an overview of the service performance of the unit concerned (Decree of the Minister for Administrative and Bureaucratic Reform Number 25 of 2004).

"Pemberian pelayanan kepada masyarakat pengguna jasa disebabkan adanya kendala internal dan eksternal. Kendala internal meliputi peralatan pendukung yang tidak memadai, kualitas SDM rendah dan koordinasi antar unit. Sarana dan prasarana yang tidak memadai yang dimiliki oleh instansi sering menghambat pemberian pelayanan kepada pengguna jasa."

"In providing services to service users, there are internal and external constraints. Internal constraints include inadequate supporting equipment, low quality of human resources, and coordination problem between units. Inadequate facilities and infrastructure in the office often hinder the provision of services to service users." (CT, Head of General Affairs Sub-Division) 
According to Moenir (2006), in order for services to satisfy an individual or group of people, public service officer must be able to meet four main requirements, namely: (a) Polite behavior, (b) the way they deliver something related to what should be received by service user concerned, (c) Right delivery time and, (d) Cordiality. Besides, the relatively low quality of human resources has further hampered the provision of public services. The low quality of human resources is indicated by the inability of officers to provide solutions to customers.

"Pelayanan merupakan salah satu ujung tombak dari upaya pemuasan pelanggan dan sudah merupakan keharusan yang wajib dioptimalkan baik oleh individu maupun organisasi, karena dari bentuk pelayanan yang diberikan tercermin kualitas individu atau organisasi yang memberikan pelayanan."

Service is one of the spearheads of programs to satisfy customers and must be optimized by individuals and organizations. It is because the service provided is a reflection of the quality of the individual or organization that provides the service." (LB, Cooperatives and SME Section)

The concept of public service can simply be described as providing services (serving) to meet the needs of people or the public who have an interest in following predetermined basic rules and procedures (Berman et al., 2019). Public service is a crucial issue in bureaucratic reform, which continues to develop and is widely criticized today. The purpose of public service is basically to satisfy and fulfill the needs of the people in general. To achieve this, service quality that meets public expectations is needed (Milakovich, 1991). The quality of public services is a benchmark for assessing public services' performance in a public service provider institution. According to Pasalong (2010):

"Kualitas pada dasarnya merupakan kata yang menyandang arti relatif bersifat abstrak, kualitas dapat digunakan untuk menilai atau menentukan tingkat penyesuaian suatu hal terhadap persyaratan atau spesifikasinya itu terpenuhi berarti kualitas suatu hal yang dimaksud dapat dikatakan baik, sebaliknya jika persyaratan tidak terpenuhi maka dapat dikatakan tidak baik. Secara teoritis, tujuan pelayanan publik pada dasarnya adalah memuaskan masyarakat."

Quality is a word that has a relatively abstract meaning. Quality can be used to assess or determine the level of adjustment of a thing to the requirements or specifications. If the requirements are met, it means that the quality of a thing in question can be said to be good. On the other hand, if the requirements are not met, it can be harmful. Theoretically, the purpose of public service is basically to satisfy the public."

The goals of the Yahukimo Regency are reflected in the vision and mission statements, which are the points that the organization will achieve or produce. The goals are quantitative targets and are the achievement of key performance indicators in the Yahukimo Regency scope. The goals must be actionable, specific, realistic, measurable, have action orientation, and have precise timing to achieve the set goals (Fried \& Slowik, 2004). There are many goals in the organization. These goals are stated in various levels, where the upper-level goals become a reference and are described in steps at the lower level. Every employee must understand the goals, how to do activities to help achieve work unit goals, and how to work unit activities contribute to its strategic goals. 


\section{b. Target}

When you want to do business activities, you need a concept. A straightforward concept such as one's necessity or wants and demands are based on a prior observation. It is either before doing a business or while developing the business. Initially, public needs in the local area must be identified. Then, it is followed by a simple question about who has provided the public needs. The question is about the level of competition with other parties if the public services provided are relatively the same.

"Sasaran merupakan penjabaran dari tujuan, yaitu apa yang akan dicapai atau dihasilkan oleh Dinas Perindustrian, Perdagangan dan Koperasi Kabupaten Yahukimo dalam jangka waktu tertentu. Sasaran pelayanan publik harus spesifik, terukur, jelas kriterianya, memiliki indikator yang rinci sehingga bisa tercapai secara efektif dan efisien".

"Target is an elaboration of the goal, which is what the Office of Industry, Trade, and Cooperatives of Yahukimo Regency will achieve or produce within a certain period. Public service targets must be specific and measurable, have clear criteria, and have clear indicators so that they can be achieved effectively and efficiently." (MH, Head of the Office of Trade, Industry, and Cooperative of Yahukimo Regency)

\section{"Sasaran kualitas pelayanan diberikan kepada konsumen harus berfungsi untuk lebih memberikan kepuasan yang maksimal, oleh karena itu dalam rangka memberikan pelayanan harus dilakukan sesuai dengan fungsi pelayanan." \\ "The target of service quality given to consumers must function to provide more maximum satisfaction. Therefore, services must be provided per the service function." (LB, Cooperative and SME Section)}

The results of the interview indicated that after public needs were identified, usually the identification was still general, so it needed much more detailed identification. Discussing what the public wants to meet their needs is classified as conducting a priority needs analysis. As a public service agency, the Yahukimo Regency must create programs and implement them according to public needs and requests in a prioritized and sustainable manner.

\section{Conclusion}

Based on research and discussion of public services at the Office of Industry, Trade, and Cooperatives of Yahukimo Regency, it can be concluded that the principles of public service in the Yahukimo Regency were assessed based on three aspects, namely: 1) Transparency. The public is increasingly motivated to convey their demands, requests, and aspirations to the government. This finding means that the public is increasingly aware of their rights and obligations as citizens. The society condition requires the public bureaucracy to provide public services that are more professional, effective, simple, transparent, open, timely, responsive, and adaptive, 2) Accountability. Service can be accounted for following the provisions of laws and regulations. Accountability in public services, according to technical and administrative requirements, must be clear and can be accounted for in terms of the quality and validity of services that run well. 3) Participation. Public participation in public services still lacks due to several factors, including low education levels, a low socioeconomic status that makes people less likely to have the resources to participate effectively, and sociocultural barriers. Those conditions make people reluctant to be involved in the system service at the level of the smallest public group. Also, the lack of public trust in the government creates public apathy in the public service process. 


\section{References}

Agere, S. (2000). Promoting good governance: Principles, practices and perspectives (Vol. 11). Commonwealth Secretariat.

Barth, F. (2010). Introduction to ethnic groups and boundaries: The social organization of cultural difference. Selected Studies in International Migration and Immigrant Incorporation, 1, 407.

Berman, E. M., Bowman, J. S., West, J. P., \& Van Wart, M. R. (2019). Human resource management in public service: Paradoxes, processes, and problems. CQ Press.

Bovaird, T. (2007). Beyond engagement and participation: User and community co-production of public services. Public administration review, 67(5), 846-860.

Cattell, V. (2001). Poor people, poor places, and poor health: the mediating role of social networks and social capital. Social science \& medicine, 52(10), 1501-1516.

Dawes, S. S. (2010). Stewardship and usefulness: Policy principles for information-based transparency. Government Information Quarterly, 27(4), 377-383.

Debrah, E. (2011). Measuring governance institutions' success in Ghana: the case of the electoral commission, 1993-2008. African Studies, 70(1), 25-45.

Eversole, R. (2012). Remaking participation: challenges for community development practice. Community development journal, 47(1), 29-41.

Fried, Y., \& Slowik, L. H. (2004). Enriching goal-setting theory with time: An integrated approach. Academy of management Review, 29(3), 404-422.

Grout, P. A., \& Stevens, M. (2003). The assessment: financing and managing public services. Oxford Review of economic policy, 19(2), 215-234.

Grubb, T. (2007). Performance appraisal reappraised: it's not all positive. Journal of Human Resources Education, 1(1), 1-22.

Hadiyati, E. (2014). Service quality and performance of public sector: Study on immigration office in Indonesia. International Journal of Marketing Studies, 6(6), 104-117.

Hanis, M. H. (2012). A public asset management framework for Indonesian local governments (Doctoral dissertation, Queensland University of Technology).

Hartley, J. (2005). Innovation in governance and public services: Past and present. Public money and management, 25(1), 27-34.

Heath, R. L., \& Palenchar, M. J. (2008). Strategic issues management: Organizations and public policy challenges. Sage Publications.

Irvin, R. A., \& Stansbury, J. (2004). Citizen participation in decision making: is it worth the effort?. Public administration review, 64(1), 55-65.

Jehanzeb, K., \& Bashir, N. A. (2013). Training and development program and its benefits to employee and organization: A conceptual study. European Journal of business and management, 5(2), 243-252.

Luthans, F., \& Youssef, C. M. (2004). Human, social, and now positive psychological capital management: Investing in people for competitive advantage. Organizational Dynamics, 33(2), 143-160.

Mahendra, W., Pratiwi, M., \& Prawesti, R. (2014). Citizens' Aspirations and Complaints Online System (LAPOR) in Indonesia: Making Citizens Happy. WCPA, 1-15.

Mahsyar, A. (2011). Masalah pelayanan publik di Indonesia dalam perspektif administrasi publik. Otoritas: Jurnal Ilmu Pemerintahan, 1(2).

Milakovich, M. E. (1991). Total quality management in the public sector. National Productivity Review, 10(2), 195-213.

Miles, M. B., \& Huberman, A. M. (1992). Analisis data kualitatif. UI press.

Moenir. (2006). Manajemen Pelayanan Umum di Indonesia. Jakarta: PT. Bumi Aksara.

Muñuzuri, J., Larrañeta, J., Onieva, L., \& Cortés, P. (2005). Solutions applicable by local administrations for urban logistics improvement. Cities, 22(1), 15-28. 
Na-Nan, K., Kanthong, S., Joungtrakul, J., \& Smith, I. D. (2020). Mediating Effects of Job Satisfaction and Organizational Commitment between Problems with Performance Appraisal and Organizational Citizenship Behavior. Journal of Open Innovation: Technology, Market, and Complexity, 6(3), 64.

Nuriyanto, N. (2014). Penyelenggaraan Pelayanan PublikDi Indonesia, Sudahkah Berlandaskan Konsep "Welfare State"? Jurnal Konstitusi, 11(3), 428-453.

O’Boyle, I. (2013). Individual performance management: A review of current practices. APMBA (Asia Pacific Management and Business Application), 1(3), 157-170.

Prasetyo, H. (2020). A Humanistic Approach of Public Services Implementation as an Effort To Achieve Good Governance. Jurnal Ilmiah Ilmu Administrasi Publik, 10(2), 466473.

Rahmat, M. (2011). Sasaran Kinerja Pegawai. Pusdiklat Kepegawaian.

Rante, A., \& Warokka, A. (2016). Leadership style, decentralisation and managerial performance: Does the management accounting system mediate the relationship?. Journal for Global Business Advancement, 9(1), 79-89.

Republik Indonesia. Undang-Undang Republik Indonesia Nomor 25 Tahun 2000 tentang Program Pembangunan Nasional (PROPENAS).

Rothstein, B. O., \& Teorell, J. A. N. (2008). What is quality of government? A theory of impartial government institutions. Governance, 21(2), 165-190.

Rukayat, Y. (2018). Kualitas pelayanan publik bidang administrasi kependudukan di kecamatan pasirjambu. Jurnal Ilmiah Magister Administrasi, 11(2), 56-65.

Sasser, W. E., Olsen, R. P., \& Wyckoff, D. D. (1978). Management of Service Operations: Text and Cases. Boston: Allyn \& Bacon.

Sinambela, L. P., Rochadi, S., Ghazali, R., Muksin, A., Setiabudi, D., Bima, D., \& Syaifudin. (2011). Reformasi Pelayanan Publik: Teori, Kebijakan, dan Implementasi. Bumi Aksara.

Spicker, P. (2009). The nature of a public service. Intl Journal of Public Administration, 32(11), 970-991.

Székely, F., \& Knirsch, M. (2005). Responsible leadership and corporate social responsibility: Metrics for sustainable performance. European Management Journal, 23(6), 628-647.

Tasca, J. E., Ensslin, L., Ensslin, S. R., \& Alves, M. B. M. (2010). An approach for selecting a theoretical framework for the evaluation of training programs. Journal of European Industrial Training, 34(7), 631-655. https:// doi.org/10.1108/03090591011070761

Wang, X. (2002). Assessing administrative accountability: Results from a national survey. The American Review of Public Administration, 32(3), 350-370.

Warokka, A. (2013). Fiscal decentralization and special local autonomy: evidence from an emerging market. Journal of Southeast Asian Research, 2013, 1.

Wihantoro, Y., Lowe, A., Cooper, S., \& Manochin, M. (2015). Bureaucratic reform in postAsian crisis Indonesia: The directorate general of tax. Critical Perspectives on Accounting, 31, 44-63.

Yang, K., \& Holzer, M. (2006). The performance-trust link: Implications for performance measurement. Public administration review, 66(1), 114-126. 